\title{
輝石温度計の評価と改良
}

\section{Evaluations and a revision of the pyroxene geothermometry}

\author{
石橋 秀巳 (Hidemi IsHiBASHI) ${ }^{*}$ \\ 池田 剛 (Takeshi IkEDA)
}

\begin{abstract}
This study evaluates the validity of several pyroxene geothermometers by comparing calculations with recent experimental studies that cover wide range of pressure and pyroxene composition. The most accurate thermometer for the multicomponent system among previously proposed models is that of Taylor (1998). This model yields temperatures $\pm 32^{\circ} \mathrm{C}(1 \sigma)$ for the multicomponent system, but provides temperatures lower than the experimental temperatures at low pressures in the $\mathrm{CaO}-\mathrm{MgO}-\mathrm{SiO}_{2}(\mathrm{CMS})$ system.

We propose a revised model of Wells (1977)'s pyroxene thermometer as,

$$
\ln K=\frac{3867-9.686(P-20)}{T}+5.518 \times 10^{-3} T+2.44 X_{\mathrm{Fe}}^{\mathrm{Opx}}-12.48
$$

, where the equilibrium constant $K$ is the same as that of Wood and Banno (1973). This yields temperatures $\pm 35^{\circ} \mathrm{C}(1 \sigma)$ for the multicomponent system and $\pm 21^{\circ} \mathrm{C}$ for the CMS system.
\end{abstract}

Keywords: Pyroxene geothermometer, Orthopyroxene, Clinopyroxene, Geothermometry

\section{I. はじめに}

輝石温度計は, 共存する斜方輝石と単斜輝石の間の下 記の反応の平衡定数の温度依存性を利用して平衡温度を 見積もる手法である。

$$
\left(\mathrm{Mg}_{2} \mathrm{Si}_{2} \mathrm{O}_{6}\right)_{\text {OPX }} \rightleftarrows\left(\mathrm{Mg}_{2} \mathrm{Si}_{2} \mathrm{O}_{6}\right)_{\mathrm{CPX}}
$$

Davis and Boyd (1966) が実験的に乥の有用性を示して以 来, この温度計は注目されてきた。反応 (1) を温度計に使 う利点は, まず反応 (1) の圧力依存性が小さいことであ る。また, 斜方輝石と単斜輝石を含む鉱物組み合わせか下 部地殻, 上部マントルを構成する岩石中に広く出現するた め, 適用範囲が広いことも利点のひとつといえる。こうし た利点があるので反応 (1) に関する研究は精力的に行わ れ，これまで多くの輝石温度計モデルが提案されてきた (例えば, Wood and Banno, 1973; Wells, 1977; Nickel and Brey, 1984; Bertrand and Mercier, 1986; Carlson and Lindsley, 1988; Brey and Köler, 1990; Taylor, 1998 )。これらの多く は $\mathrm{CaO}-\mathrm{MgO}-\mathrm{SiO}_{2}(\mathrm{CMS})$ 系での実験データに基づいた関 係式に，経験的な組成の関数を組み合わせてつくられてい
る。組成の関数は, $\mathrm{CMS}$ 系に $\mathrm{FeO} や \mathrm{Al}_{2} \mathrm{O}_{3}$ を加えた比較 的単純な系での実験データをもとに作成されている。こ のため,さらに複杂倠な多成分系である天然の岩石の平衡温 度をどの程度正確に再現するかは, 多成分系の実験によっ て検討される必要がある。

近年，多成分系におけるサブソリダス温度領域で平衡 な斜方輝石と単斜輝石の組み合わせの実験データが複数 報告された (Sen and Jones, 1989; Brey et al., 1990; Taylor, 1998)。また，かんらん岩溶融実験での固相鉱物の組成 データも公表されるようになり，広い温度，圧力，組成範 囲での平衡な斜方輝石と単斜輝石の組み合わせの実験 データが多数蓄積されている (例えば; Baker and Stolper, 1994; Gaetani and Grove, 1998; Pichering-Witter and Johnston, 2000; Schewab and Johnston, 2001; Wasylenki et al., 2003)。炎こで, 本研究ではこれらの実験データを用いて 代表的な輝石温度計の多成分系での再現性を検討した。 乥して, Wells (1977) の輝石温度計を改良した新しいモデ ルを提案する。

\section{II. 輝石温度計概論}

斜方輝石と単斜輝石が平衡に共存するとき，反応 (1) に

(平成 16 年 9 月 1 日受付, 平成 16 年 12 月 8 日受理)

*九州大学大学院理学府地球惑星科学専攻, ₹ 812-8581 福岡市東区箱崎 33

** 九州大学大学院理学研究院地球惑星科学部門, = 812-8581 福岡市東区箱崎 33

* Department of Earth and Planetary Sciences, Graduate School of Science, Kyushu University, 33 Hakozaki, Fukuoka 812-8581, Japan E-mail; hidemi@geo.kyushu-u.ac.jp

** Department of Earth and Planetary Sciences, Graduate School of Science, Kyushu University, 33 Hakozaki, Fukuoka 812-8581, Japan E-mail; ikeda@geo.kyushu-u.ac.jp 
ついて次式が成立する。

$0=\Delta G^{0}+R T \ln K$

ここで $\Delta G^{0}$ は平衡温度 $(T)$,圧力における $\mathrm{Mg}_{2} \mathrm{Si}_{2} \mathrm{O}_{6}$ 組成 の単斜輝石と斜方輝石のギブス自由エネルギー差である。 $R$ は気体定数, $K$ は平衡定数で次のように表される。

$$
K=\frac{a_{\mathrm{Mg}_{2} \mathrm{~S}_{2} \mathrm{O}_{6}}^{\mathrm{CP}_{\mathrm{PO}}}}{a_{\mathrm{Mg} \mathrm{g}_{2} \mathrm{~S}_{2} \mathrm{O}_{6}}}
$$

ここで $a_{\mathrm{Mg}_{2} \mathrm{~S}_{2} \mathrm{O}_{6}}$ は輝石中の $\mathrm{Mg}_{2} \mathrm{Si}_{2} \mathrm{O}_{6}$ 成分の活動度を表す。 $\Delta G^{0}$ を温度と圧力 $(P)$ の関数として展開すると式 (2) は以 下のように表せる。

$$
0=\Delta H-T \Delta S+\left(P-P_{0}\right) \Delta V+R T \ln K
$$

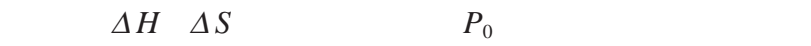
および反応エントロピー, $\Delta V$ は反応体積変化である。 (4) 式より任意の圧力における平衡温度を求めることがで きる。

輝石温度計の研究は, Davis and Boyd (1966) がCMS 系 で斜方輝石と単斜輝石の間の二相共存領域の温度依存性 を実験的に示して以来注目されてきた。初期の輝石温度 計は, $\mathrm{Fe} や \mathrm{Al}$ に乏しく $\mathrm{Mg}$ に富む斜方輝石と単斜輝石の 分析データを, 実験に基づいて描いたエンスタタイトディオプサイド系の相図と直接比較するという経験則的 なものであった(例えばDavis and Boyd, 1966; Boyd, 1969)。

輝石温度計に (4) 式のような熱力学的解析をはじめて導 入したのは Wood and Banno (1973) である。彼らは単斜輝 石, 斜方輝石の両方に理想 2 席固溶体モデルを適用し，次 式によって CMS 系での平衡定数を表した。

$$
K_{\mathrm{WB}}=\left(\mathrm{Mg}^{\mathrm{M} 2} \times \mathrm{Mg}^{\mathrm{M} 1}\right)_{\mathrm{CPX}} /\left(\mathrm{Mg}^{\mathrm{M} 2} \times \mathrm{Mg}^{\mathrm{M} 1}\right)_{\mathrm{OPX}}
$$

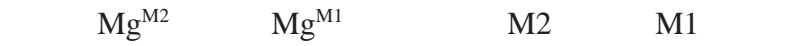
$\mathrm{Mg}$ のモル分率である。化学分析のみから席の含有量は求 められないので, $\mathrm{Mg}^{\mathrm{M} 2}$ および $\mathrm{Mg}^{\mathrm{M} 1}$ を以下の仮定に基づい て計算している。まず， $\mathrm{Ca}, \mathrm{Na}, \mathrm{Mn}$ は M2 席に, $\mathrm{Al}^{\mathrm{vi}}$, $\mathrm{Cr}, \mathrm{Ti}, \mathrm{Fe}^{3+}$ は $\mathrm{M} 1$ 席に分配される。つぎに, $\mathrm{M} 1$ 席と $\mathrm{M} 2$ 席で $\mathrm{Fe}^{2+}$ と $\mathrm{Mg}$ は均等に分配される。つまり $X_{\mathrm{Fe}}^{\mathrm{M} 2}=X_{\mathrm{Fe}}^{\mathrm{M} 1}=$ $X_{\mathrm{Fe}}^{\mathrm{PX}}\left[\right.$ ここで $\left.X_{\mathrm{Fe}}=\mathrm{Fe} /(\mathrm{Fe}+\mathrm{Mg})\right]$ 。彼らは Davis and Boyd (1966) の CMS 系実験データを, $\Delta V=0$ とおいて (4) 式に 最小二乗回帰して， $\Delta H, \Delta S$ を求めた。さらに Fe に富む 系の実験データ (Smith, 1972; Lindsley and Munoz, 1969) を 用いて, 補正項 $Z=\left[3.88 R T\left(X_{\mathrm{Fe}}^{\mathrm{OPX}}\right)^{2}-7.65 R T X_{\mathrm{Fe}}^{\mathrm{OPX}}+0.75 R T\right]$ を(4)式の右辺に加えることで,CMS 系での関係式を多成 分系へと拡張した。

Wood and Banno (1973) の提案以降にも, 斜方輝石と単 斜輝石の平衡実験力数多く行われ, $900^{\circ} \mathrm{C}$ から $1500^{\circ} \mathrm{C}$, 高 圧側 $60 \mathrm{kbar}$ までの範囲で逆実験のなされた信頼できる実

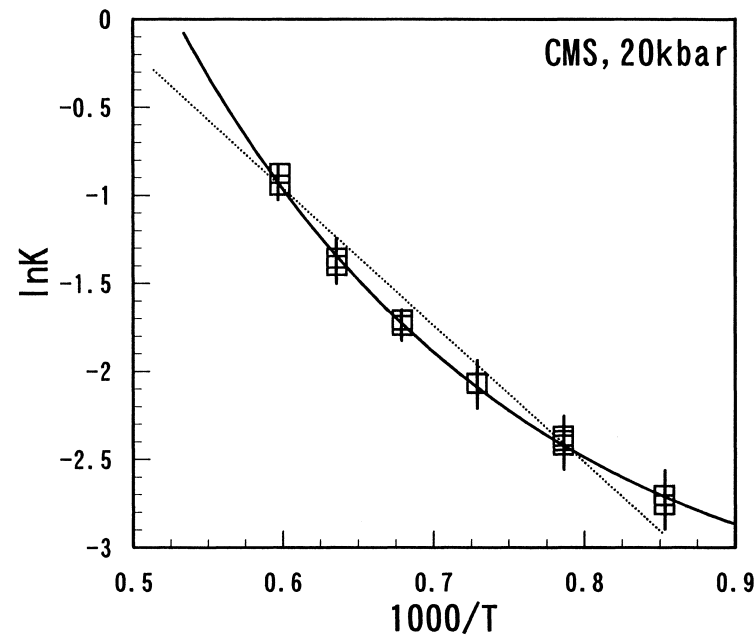

Fig. 1. Relation between $\ln K$ and reciprocal $T$ (in Kelvin) of experiments by Lindsley et al. (1976) and Perkins and Newton (1980) at $20 \mathrm{kbar}$ in the CMS system. Equilibrium constant is defined by Eq (5). Dotted line is the calibration line of Wells (1977)'s model. Solid line is defined by Eq. (9).

験データが蓄積された(例えばNehru and Wyllie, 1974; Warner and Luth,1974; Mori and Green, 1975, 1976; Lindsley and Dixon,1976; Perkins and Newton, 1980; Brey and Huth, 1984; Nickel and Brey, 1984)。これらの実験データから ,反 応 (1) の平衡定数には圧力依存性があることや(例えば Mori and Green, 1975; Lindsley et al., 1981; Nickel and Brey, 1984)， $\ln K$ は $1 / T$ に対して直線にならず，下に凸の曲線的 な関係を示すことなどがわかってきた (例えば Brey and Kohler, 1990; Fig. 1)。平衡定数の圧力依存性は Lindsley et al. (1981) 以降 , モデルに組み込まれるようになった。 $\ln K$ と $1 / T$ の曲線関係は, 輝石の非理想性て説明されたり(例 えば Nickel and Brey, 1984; Bertrand and Mercier, 1986; Carlson and Lindsley, 1988)，(4) 式を離れ $(\ln K)^{2}$ を用いた双 曲線で表現されたりしている (Brey and Kohler, 1990; Taylor, 1998)。

Wood and Banno (1973) 以降の輝石温度計に関する研究 は大きく2つに区分できる。乥のひとつは輝石温度計の開 発よりむしろ, 輝石相図を説明する熱力学モデルの開発に 重点をおいた研究である(例えばLindsley et al., 1981; Nickel and Brey, 1984; Carlson and Lindsley, 1988)。これら の研究では CMS 系を対象とし, 非理想活動度モデルを導 入して, 輝石相図を再現する熱力学的パラメーターの決定 を目的としている。このとき用いられる制約条件として 反応 (1) に加え, ディオプサイド成分に関する反応

$$
\left(\mathrm{CaMgSi}_{2} \mathrm{O}_{6}\right)_{\text {opX }} \rightleftarrows\left(\mathrm{CaMgSi}_{2} \mathrm{O}_{6}\right)_{\mathrm{CPX}}
$$

の平衡条件の両方を同時に満たすこと，ピジョン輝石の出 現温度などがあげられる。輝石温度計は, 決定された熱力 学的パラメーターを (4) 式に代入することで得ることがで きる。このタイプの輝石温度計のうち比較的高圧領域 
(<60 kbar) まで適用できるモデルとして Nickel and Brey (1984) と Carlson and Lindsley (1988) があげられる。前者 は単斜輝石と斜方輝石の両方について対称溶液モデルを 適用しており, 後者は斜方輝石について対称溶液モデル， 単斜輝石について非対称溶液モデルを適用している。こ れらの研究では反応 (1) と (6) の关れ午れに基づいて別個 の輝石温度計が得られるが, 反応 (1) に基づく輝石温度計 の方がより高精度である。これは $1000^{\circ} \mathrm{C}$ 以下の低温領域 て斜方輝石中のディオプサイド成分の濃度が低く, 分析誤 差に由来する平衡定数の誤差が大きくなるためである (Nickel and Brey, 1984)。

もうひとつは多成分系の天然の岩石に適用できる輝石 温度計の開発を目的とした研究である (例えばWells, 1977; Bertrand and Mercier, 1986; Brey and Köhler, 1990; Taylor, 1998)。これらの研究では, CMS 系で定式化した (4) 式に組成に関する補正項を加えることで, 多成分系で 使用可能な゙温度計を開発している。以下に4つの代表的な モデルについて簡単に解説する。

Wells (1977) は, 当時入手できた信頼できる高圧実験 データ (Nehru and Wyllie, 1974; Mori and Green, 1975; 1976; Lindsley and Dixon, 1976) を用いて Wood and Banno (1973) のモデルを再校正したものである。CMS 系での平衡定数 を(5) 式で与え， $\Delta V=0$ を仮定している点でWood and Banno (1973) と同じである。Wood and Banno (1973) と異 なる点は, より多くのCMS 系の実験を回帰した結果， $\Delta H, \Delta S$ の值か変わったことと, 多成分系への拡張として (4) 式の右辺に加える補正項 $Z$ を-2.44RTX $X_{\mathrm{Fe}}^{\mathrm{OPX}}$ とした。 Wood and Banno (1973) の式は多成分系での式がCMS 系で の回帰式と一致しない $\left(X_{\mathrm{Fe}}^{\mathrm{OPX}}=0\right.$ で $Z=0$ とならない) が， Wells (1977) ではこの問題が解決されている。このモデル は現在もつとも頻繁に使われている輝石温度計である。

Bertrand and Mercier (1986) は CMS 系で斜方輝石を理想 溶液, 単斜輝石を対称溶液として扱っている。分配係数 は , 輝石の M2 サイト中の元素分配のみに注目して次のよ
うに定義した。

$$
K_{\mathrm{BM}}=\left(\mathrm{Mg}^{\mathrm{M} 2}\right)_{\mathrm{CPX}} /\left(\mathrm{Mg}^{\mathrm{M} 2}\right)_{\mathrm{OPX}}=\left(1-\mathrm{Ca}^{\mathrm{M} 2}\right)_{\mathrm{CPX}} /\left(1-\mathrm{Ca}^{\mathrm{M} 2}\right)_{\mathrm{OPX}}
$$

彼らは CMS 系で分配係数と絶対温度の関係式を定式化 した。多成分系への拡張は, (7) 式中の $\mathrm{Ca}^{\mathrm{M} 2}$ のかわりに , これに Fe と $\mathrm{Na}$ に関する補正を加えたパラメーター $\left(\mathrm{Ca}^{*}\right)$ を用いることで行っている。

Brey and Kohler (1990) と Taylor (1998) のモデルは (4) 式 の形式ではなく，次式の経験則的な形式を用いている。

$$
\left(\ln K_{\mathrm{D}}\right)^{2}=\frac{a+b P}{T}+c
$$

ここで $a, b, c$ は定数である。Brey and Kohler (1990) は分配 係数 $K_{\mathrm{D}}$ を(7) 式で定義 し, Taylor (1998) は Wood and Banno (1973) と同樣，(5) 式を採用している。Brey and Kohler (1990) のモデルはまず CMS 系での分配係数と絶対 温度の関係を (7) 式に従って定式化し これに $\mathrm{Na}$ と $\mathrm{Fe}$ に 関する補正を加えて多成分系に拡張している。一方 Taylor (1998) は他の研究と異なり，CMS 系データを用い ないで直接多成分系データを用いて分配係数と絶対温度 の関係式を得ている。

\section{III. 輝石温度計の評価}

1. 評価方法と実験データ

公表されている単斜輝石と斜方輝石の平衡実験データ に実際に輝石温度計を適用し，見積もられた温度と実験温 度を比較することによって, 既存の輝石温度計を評価し た。CMS 系実験データは Nickel and Brey (1984)および Bertrand and Mercier (1986) によって編集されたデータ セットを用いた。このデータセットはすべて逆実験がな されている。CMS 系実験データの温度圧力範囲は 15～60 kbar , 900〜 $1500^{\circ} \mathrm{C}$ である。多成分系データのデータソー

Table 1. Data sources of multicomponent experiments and experimental conditions

\begin{tabular}{llcc}
\hline \multicolumn{1}{c}{ Reference } & $\mathrm{P}(\mathrm{kbar})$ & $\mathrm{T}\left({ }^{\circ} \mathrm{C}\right)$ \\
\hline & & & \\
& Akella (1976) & $3-44$ & $1100-1300$ \\
Sub-solidus & Sen and Jones (1989) & $10-15$ & $925-1150$ \\
& Brey et al. (1990) & $10-60$ & $900-1400$ \\
& Taylor (1998) & $10-35$ & $1050-1260$ \\
& & & \\
\hline & Falloon and Green (1987) & 10 & $1230-1400$ \\
& Baker and Stolper (1994) & 10 & $1270-1330$ \\
& Gaetani and Grove (1998) & $12-20$ & $1170-1370$ \\
& Pickering-Witter and Johnston (2000) & 10 & $1260-1300$ \\
& Schewab and Johnston (2001) & 10 & $1245-1345$ \\
& Wasylenki et al. (2003) & 10 & $1250-1325$ \\
& & & \\
\hline
\end{tabular}



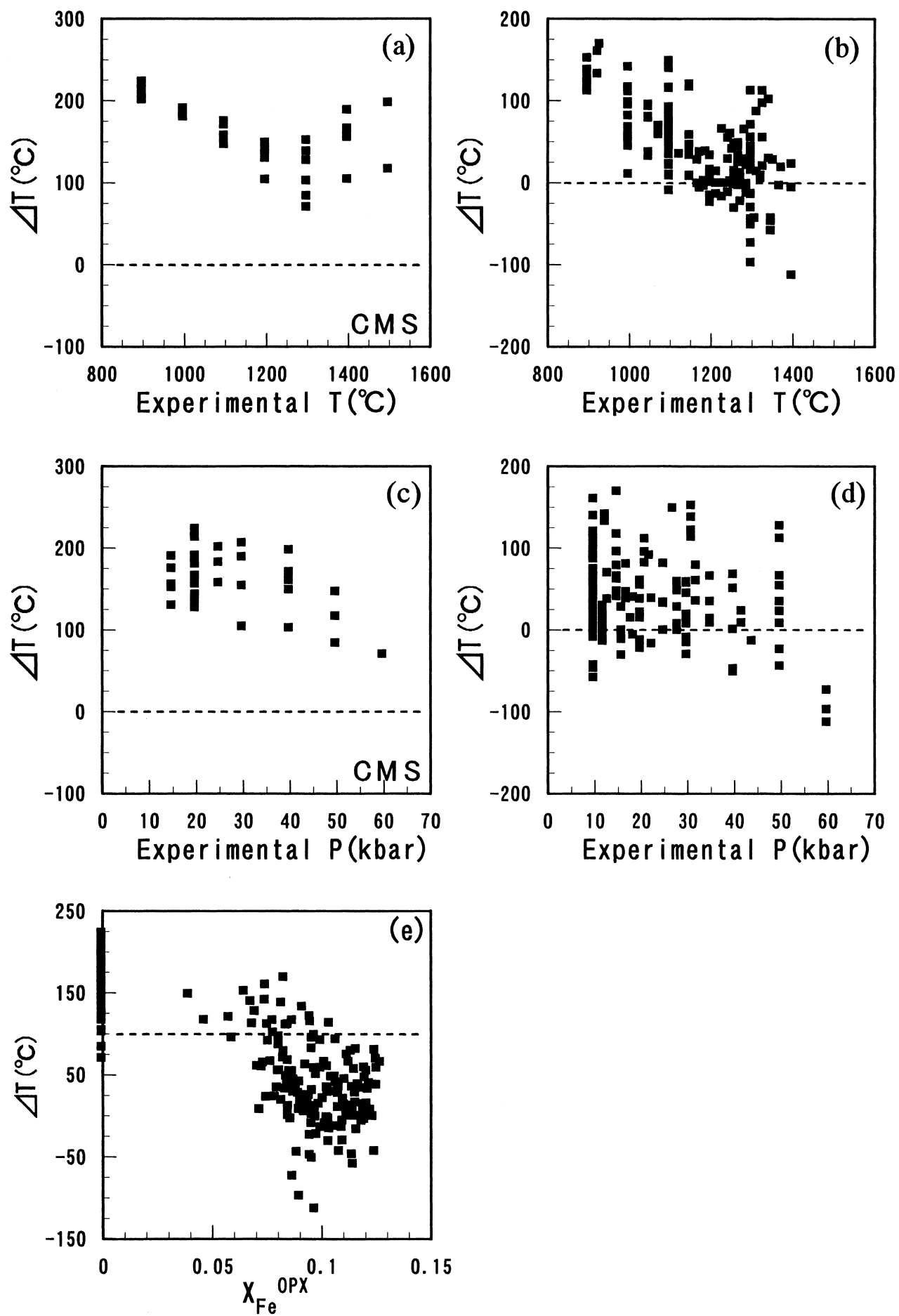

Fig. 2. Comparisons between experimental conditions and $\Delta T$ of Wood and Banno (1973)'s model. Data sources for the multicomponent system are listed in Table 1. $\Delta T$ vs. experimental temperatures in the CMS system (a) and the multicomponent system (b). $\Delta T$ vs. experimental pressures in the CMS system (c) and the multicomponent system (d). (e) $\Delta T$ vs. $X_{\mathrm{Fe}}^{\mathrm{OPX}}$.

スを Table 1 に示す。多成分系データは逆実験が行われて いないので,以下のような条件を満たすものだけを採用し た。ピジョン輝石が出現する実験データは除外した。分 析した斜方輝石, 単斜輝石の陽イオンのモル数か酸素 6 に 対して $4 \pm 0.02$ の範囲内のデータのみ採用した。実験中
に Fe が系外に散逸する問題を避けるためにグラファイト カプセルまたはかんらん石カプセルを用いた実験のみを 採用した。乥の結果, 実験の温度範囲は 900〜 $1400^{\circ} \mathrm{C}$, 圧 力範囲は $10 \sim 60 \mathrm{kbar}, X_{\mathrm{Fe}}^{\mathrm{PX}}$ は斜方輝石, 単斜輝石とも 0.04 〜 0.14 の範囲である。また斜方輝石は $\mathrm{Al}_{2} \mathrm{O}_{3}<8$ wt.\% , 単 

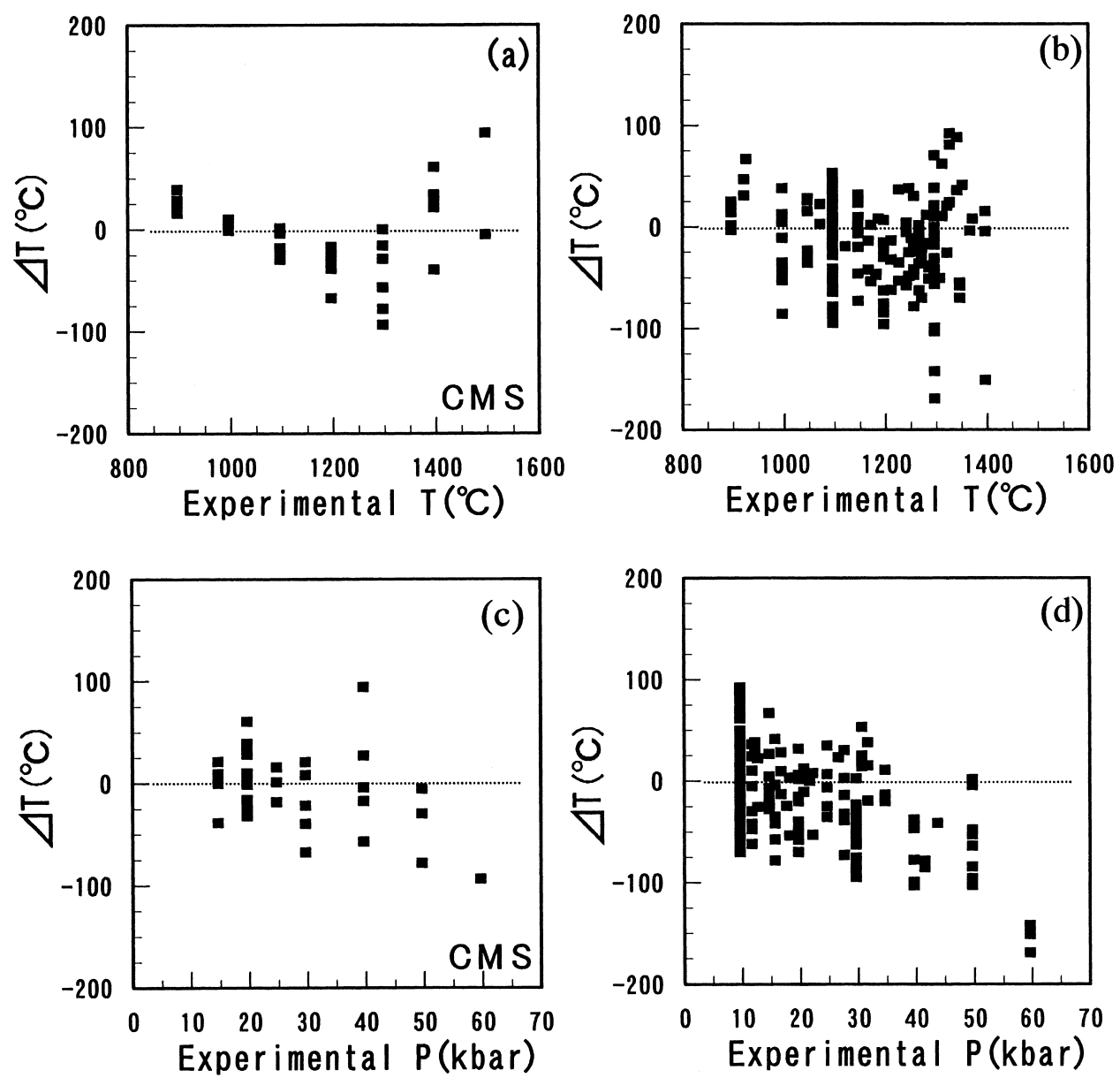

Fig. 3. Comparisons between experimental conditions and $\Delta T$ of Wells (1977)'s model. Data are the same as those in Figure 2. $\Delta T$ vs. experimental temperatures in the CMS system (a) and the multicomponent system (b). $\Delta T$ vs. experimental pressures in the CMS system (c) and the multicomponent system (d).

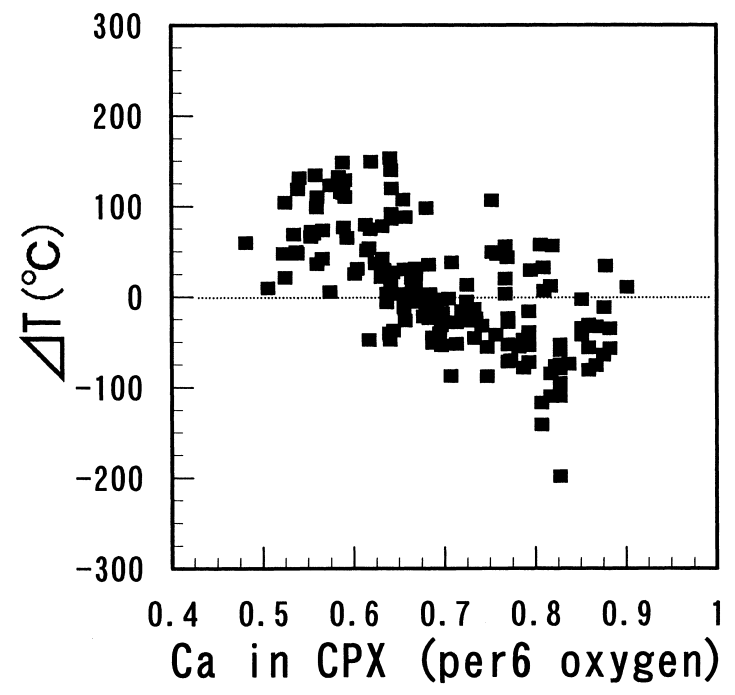

Fig. 4. Ca content in clinopyroxene (CPX) and $\Delta T$ of Bertrand and Mercier (1986)'s model in the multicomponent system. Data are the same as those in Figure 2.

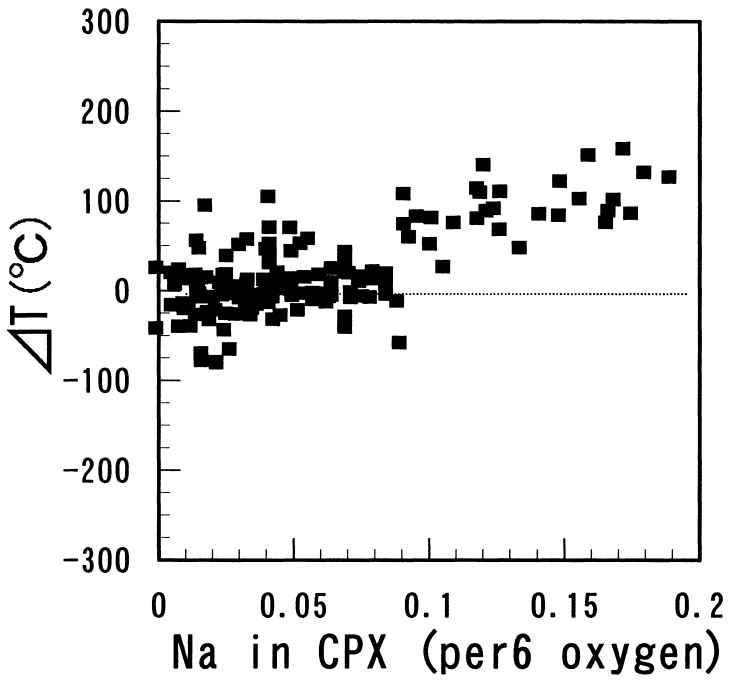

Fig. 5. Na content in clinopyroxene (CPX) and $\Delta T$ of Brey and Kohler (1990)'s model in the multicomponent system. Data are the same as those in Figure 2. 


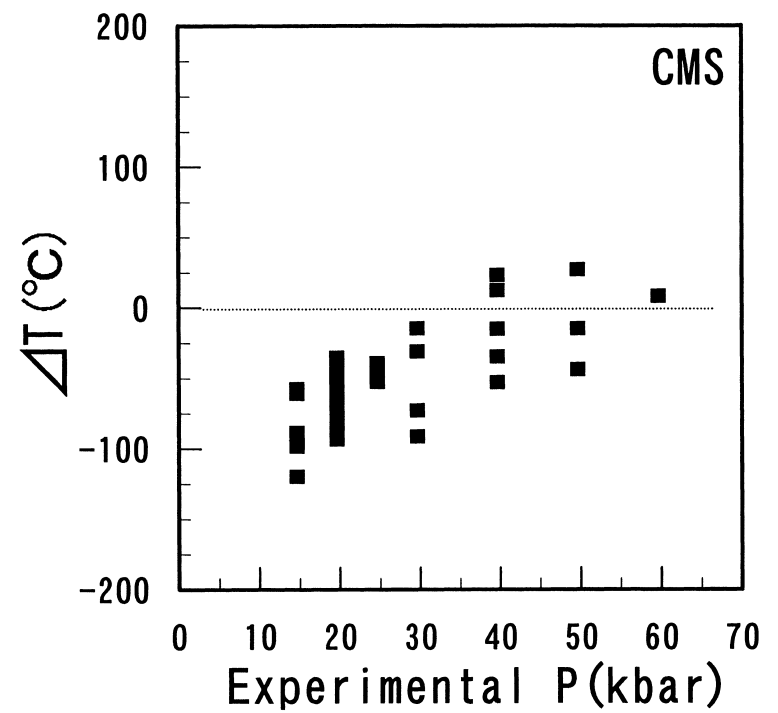

Fig. 6. Experimental pressure and $\Delta T$ of Taylor (1998)'s model in the CMS system. Data are the same as those in Figure 2.

斜輝石は $\mathrm{Al}_{2} \mathrm{O}_{3}<9$ wt.\%, $\mathrm{Na}_{2} \mathrm{O}<3$ wt. \% である。

評価した輝石温度計は Wood and Banno (1973), Wells (1977) ,Bertrand and Mercier (1986) ,Brey and Kohler (1990) Taylor (1998), Nickel and Brey (1984)，およびCarlson and Lindsley (1988)の7つである。これらのうち, 最後の2つ は多成分系に拡張していないので CMS 系のみを評価し た。他の 5 つに関しては CMS 系および多成分系の実験結 果と比較した。

2. 結果

実験温度と各モデルで算出される温度との差 $\Delta T$ (=見積もり温度 - 実験温度) と, 実験温度, 実験圧力, 輝石 の組成との相関を調べ, 各モデルの特性を調べた。Wood and Banno (1973)のモデルは,CMS 系と多成分系の両方で $\Delta T$ と温度 , 圧力の間に相関がみられる。実験温度 $900^{\circ} \mathrm{C}$ から $1300^{\circ} \mathrm{C}$ にかけて $\Delta T$ は, $\mathrm{CMS}$ 系ではおよ光+200 ${ }^{\circ} \mathrm{C}$ ら $+100^{\circ} \mathrm{C}$ まで(Fig. $\left.2 \mathrm{a}\right)$ ，多成分系ではおよ光 $+150^{\circ} \mathrm{C}$ から $0^{\circ} \mathrm{C}$ まで減少する (Fig. 2b)。CMS 系では実験温度 $1300^{\circ} \mathrm{C}$ 以上で再び $\Delta T$ か増加する傾向がみられる。また CMS 系 と多成分系のいずれでも圧力の増加に伴って $\Delta T$ が減少す る傾向がみられる (Fig. 2c, d)。さらに $X_{\mathrm{Fe}}^{\mathrm{OPX}}$ と $\Delta T$ の間にも 相関がみられ， $X_{\mathrm{Fe}}^{\mathrm{OPX}}$ が小さい方が $\Delta T$ が大きい (Fig. 2e)。 CMS 系で系統的に高温を示すことから，CMS 系でのモデ ルに問題があると考えられる。また CMS 系と多成分系で $\Delta T$ の大きさが著しく異なることから (Fig. 2a, b) , CMS 系 から多成分系へ拡張する項にも問題があるのであろう。

Wells (1977) のモデルでは CMS 系と多成分系の間で $\Delta T$ に著しい差はみられなかった (Fig. 3)。このモデルでも温 度，圧力に対して系統誤差がみられた (Fig. 3)。CMS 系と 多成分系の両方で, 実験温度 $900^{\circ} \mathrm{C}$ から $1300^{\circ} \mathrm{C}$ にかけて $\Delta T$ が $+30^{\circ} \mathrm{C}$ から $-50^{\circ} \mathrm{C}$ まで減少し, $1300^{\circ} \mathrm{C}$ 以上で再び $\Delta T$ か増加した (Fig. 3a, b)。またCMS 系と多成分系の両方 で圧力の増加に伴って $\Delta T$ が減少する傾向がみられた (Fig. 3c, d)。CMS 系と多成分系の間で $\Delta T$ に差がみられな かったことから，多成分への拡張がうまく行われていると いえる。一方で, CMS 系でも系統誤差を生じることから， CMS 系でのモデルに問題があると考えられる。この点に ついて次章で改善する。

Bertrand and Mercier (1986)のモデルは , CMS 系では温 度,圧力のいずれに対しても系統誤差はみられない。一方 で $\Delta T$ は単斜輝石中の Ca 含有量と明瞭な相関を示し, 単 斜輝石中の $\mathrm{Ca}$ 含有量の少ないサンプルほど $\Delta T$ が大きい 傾向がみられる (Fig. 4)。このことからこのモデルのCMS 系でのモデルは問題ないが,多成分への拡張は適当でない といえる。

Brey and Kohler (1990)の $\Delta T$ は温度, 圧力に対しては相 関がみられなかった。一方で $\Delta T$ は単斜輝石中の $\mathrm{Na}$ 含有 量と相関を示す (Fig. 5)。単斜輝石中の $\mathrm{Na}$ 含有量か酸素 6 に対して 0.1 以上のサンプルでは $100^{\circ} \mathrm{C}$ 程度高めに出る傾 向がみられる。このことからこのモデルの CMS 系でのモ デルは問題ないが, 多成分への拡張は適当でないといえ る。

Table 2. Summry of evaluation of the pyroxene geothermometers in terms of mean value of $\Delta T\left(\Delta T_{\mathrm{M}}\right)$ and standard deviation $(\sigma)$

\begin{tabular}{|c|c|c|c|c|c|c|c|c|}
\hline & WB73 & W77 & BM86 & BK90 & T98 & NB84 & CL88 & $\begin{array}{l}\text { This } \\
\text { study }\end{array}$ \\
\hline \multicolumn{9}{|l|}{ CMS } \\
\hline Mean $\Delta \mathrm{T}\left(\Delta \mathrm{T}_{\mathrm{M}}\right)$ & 156 & -8 & 0 & 3 & -52 & 2 & -30 & 1 \\
\hline Standard deviation $(\sigma)$ & 37 & 37 & 19 & 20 & 35 & 29 & 44 & 21 \\
\hline \multicolumn{9}{|l|}{ Multicomponent } \\
\hline Mean $\triangle \mathrm{T}\left(\triangle \mathrm{T}_{\mathrm{M}}\right)$ & 37 & -19 & 5 & 16 & -11 & - & - & -5 \\
\hline Standard deviation $(\sigma)$ & 51 & 45 & 66 & 47 & 32 & - & - & 35 \\
\hline
\end{tabular}

Abbreviations: WB73, Wood and Banno (1973); W77, Wells (1977); BM86, Bertrand and Mercier (1986); BK90, Brey and Kohler (1990); T98, Taylor (1998); NB84, Nickel and Brey (1984); CL88, Carlson and Lindsley (1988). 

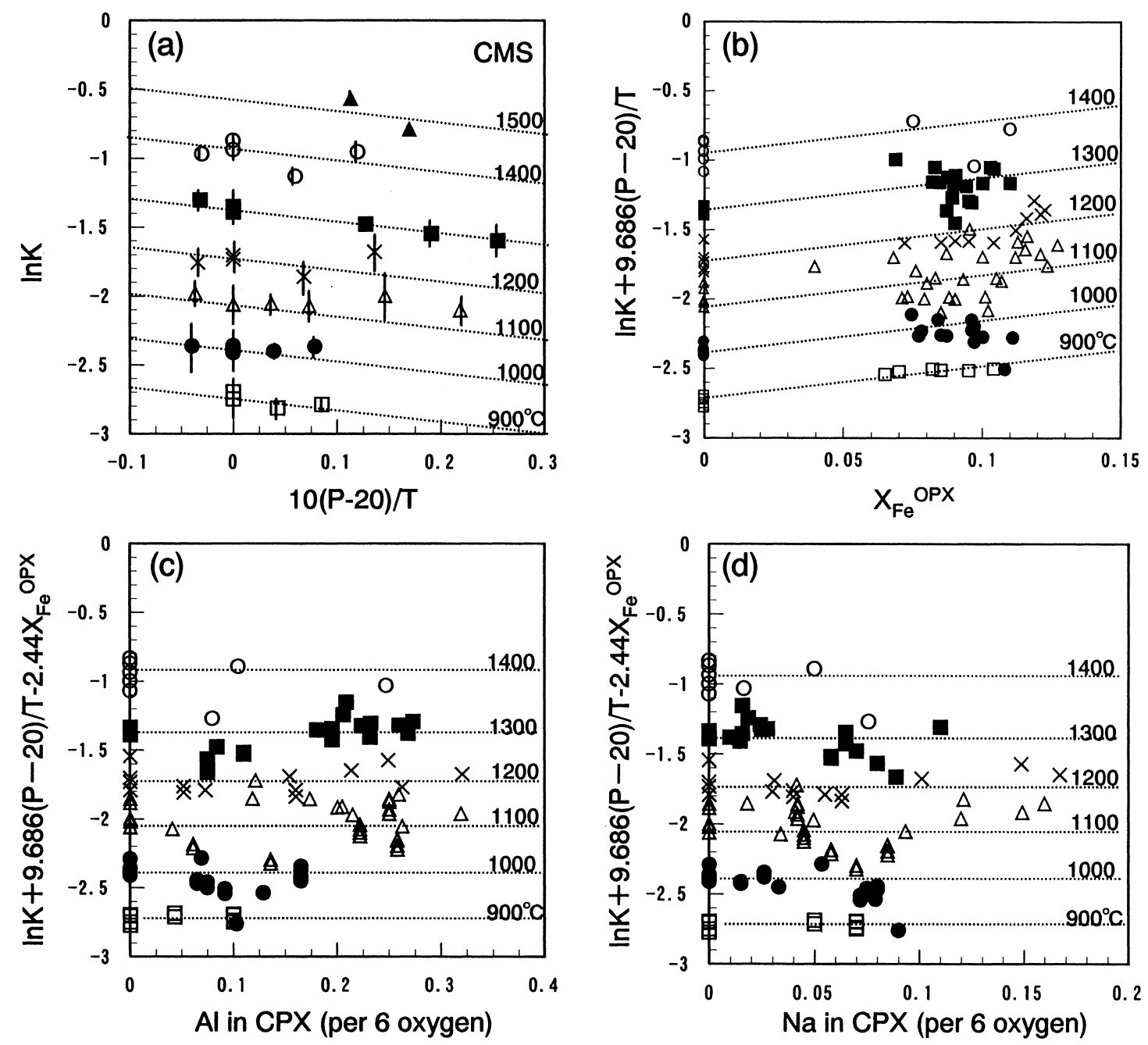

Fig. 7. Progressive correction of $\ln K$ with respect to pressure (a) and composition of orthopyroxene (b), together with $\mathrm{Al}$ and Na contents in clinopyroxene (c,d). Dotted lines in (a) are defined by Eqs. (11), those in (b), (c) and (d) are by Eq. (13). Symbols are as follows. Open square, $900^{\circ} \mathrm{C}$; filled circle, $1000^{\circ} \mathrm{C}$; open triangle, $1100^{\circ} \mathrm{C}$; cross, $1200^{\circ} \mathrm{C}$; filled square, $1300^{\circ} \mathrm{C}$; open circle, $1400^{\circ} \mathrm{C}$; filled triangle, $1500^{\circ} \mathrm{C}$.

Taylor (1998)の $\Delta T$ は CMS 系では圧力に対して相関が

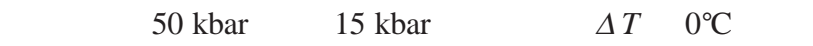
$-100^{\circ} \mathrm{C}$ まで変化する (Fig. 6)。一方で多成分系では温度， 圧力, 組成のいずれに対しても明瞭な相関がみられなかっ た。既存の輝石温度計ではこのモデルがもつともよく実 験温度を再現できる。

上述の 5 つのモデルの $\Delta T$ の平均值,$\Delta T_{\mathrm{M}}$, と炎の標準 誤差 $\sigma$ を Table 2 にまとめる。多成分系への拡張のない 2 つのモデル (Nickel and Brey, 1984; Carlson and Lindsley, 1988) の結果も合わせて示す。CMS 系でもつとも $\Delta T_{\mathrm{M}}, \sigma$ が 小さいのは Bertrand and Mercier (1986) と Brey and Kohler (1990)のモデルである。これらに続いて Nickel and Brey (1984)のモデルが $\Delta T_{\mathrm{M}}, \sigma$ が小さい。多成分系でもっ とも $\Delta T_{\mathrm{M}}, \sigma$ が小さいのは Taylor (1998)のモデルである。 CMS 系でもっとも $\Delta T_{\mathrm{M}}, \sigma$ が小さかった Bertrand and Mercier (1986) のモデルは, $\Delta T_{\mathrm{M}}$ は小さいが $\sigma$ は大きい。 これは前述の単斜輝石の Caに $\Delta T$ が相関を持つことに起
因する。Wells (1977) と Brey and Kohler (1990) のモデルは $\Delta T_{\mathrm{M}}, \sigma$ ともに大きい。Nickel and Brey (1984) のモデルで は $\Delta T$ は実験温度, 圧力に対して相関を示さない。 Carlson and Lindsley (1988) のモデルの $\Delta T$ も実験温度 , 圧 力に対して相関を示さないが , 平均的に $30^{\circ} \mathrm{C}$ 程度低めに 温度を見積もる傾向がみられる。

\section{Wells (1977) の輝石温度計の改良}

前述のようにWells (1977)のモデルは多成分系への拡張 がうまく説明できている。しかし $\ln K$ と $1 / T$ の関係を直線 近似することによって $\Delta T$ が大きくなっている。光こで Wells (1977) カ採用した平衡定数 [(5) 式]を用いて,CMS 系での $\ln K$ と $1 / T$ の関係を曲線近似するモデルを提案す る。さらに圧力依存性を評価し, 最後に多成分系への拡張 を試みた。

まず $\ln K$ と $1 / T$ の間の曲線的関係 (Fig. 1) を二次曲線に

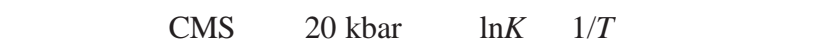


二乗回帰すると次式が得られる。

$$
\ln K_{\mathrm{CMS}, 20 \mathrm{kbar}}=\frac{3867}{T}+5.518 \times 10^{-3} T-12.48
$$

(9) 式は CMS 系, $20 \mathrm{kbar}$ のデータの実験温度を $\Delta T_{\mathrm{M}}=$ $-2^{\circ} \mathrm{C}, \sigma=9^{\circ} \mathrm{C}$ で再現できる。(9) 式は経験則的なもので あり，この式の熱力学的な意味は現在考察中である。

次に圧力依存性について考える。(4) 式より温度一定の とき，任意の圧力での $\ln K\left(P, T_{0}\right)$ は圧力 $P_{0}$ での $\ln K\left(P_{0}, T_{0}\right)$ と $\Delta V$ によって次式で表すことができる。

$$
\ln K\left(P, T_{0}\right)=\ln K\left(P_{0}, T_{0}\right)-\frac{\Delta V}{R} \frac{\left(P-P_{0}\right)}{T_{0}}
$$

(10) 式は $\ln K$ を $P / T$ の一次関数として記述できることを示 している。光こで Figure 7a に CMS 系での $\ln K_{\mathrm{CMS}}$ と $(P-$ 20)/T の関係を示した。 $1300^{\circ} \mathrm{C}$ における任意の圧力での $\ln K_{\mathrm{CMS}}$ と $20 \mathrm{kbar} て ゙ の ~ \ln K_{\mathrm{CMS}, 20 \mathrm{kbar}}$ との間には次式の関係が みられる。

$$
\ln K_{\mathrm{CMS}}=\ln K_{\mathrm{CMS}, 20 \mathrm{kbar}}-9.686(P-20) / T \quad(P ; \mathrm{kbar})
$$

ここで係数 9.686 は $1300^{\circ} \mathrm{C}$ のデータから最小二乗法によ り求めた值である。この関係は他の温度のデータについ ても成り立つ(Fig. 7)。(11) 式中の係数 9.686 は $\Delta V / R$ に相 当するので, これから $\Delta V=80.53(\mathrm{~J} / \mathrm{kbar} / \mathrm{mol})$ と見積もら れる。(9),(11) 式より CMS 系での任意の圧力での $\ln K_{\mathrm{CMS}}$ と $T$ の関係が次式で与えられる。

$$
\ln K_{\mathrm{CMS}}=\frac{3867-9.686(P-20)}{T}+5.518 \times 10^{-3} T-12.48
$$

(12) 式は $\mathrm{CMS}$ 系のデータの害験温度を $\Delta T_{\mathrm{M}}=1^{\circ} \mathrm{C}, \sigma=$ $21^{\circ} \mathrm{C}$ で再現できる (Table 2)。

前章で述べたように，Wells (1977)のモデルは CMS 系か ら多成分系への拡張をうまく説明している。弚こで， (12) 式に Wells (1977) が行った補正項 $Z=-2.44 R T X_{\mathrm{Fe}}^{\mathrm{OPX}}$ を

(12) 式の右辺に加え, 以下の式を得た。

$$
\begin{aligned}
\ln K= & \frac{3867-9.686(P-20)}{T}+5.518 \times 10^{-3} T+2.44 X_{\mathrm{Fe}}^{\mathrm{Opx}} \\
& -12.48
\end{aligned}
$$

Figure $7 \mathrm{~b}$ は斜方輝石中の $X_{\mathrm{Fe}}^{\mathrm{OPX}}$ と圧力について補正した $\ln K$ との関係を示したものである。Wells (1977)の補正式 を各温度について点線で示してある。これによると Wells (1977)の補正式は $\ln K$ に対する Fe の影響をよく補正して いることがわかる。Figure 7c および7d は光れ光れ単斜輝

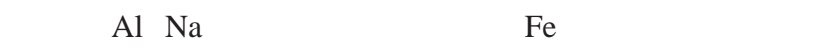
$\ln K$ との関係を示したものである。Feについて補正した $\ln K$ は $\mathrm{Na}$ や $\mathrm{Al}$ と相関をもたない。Crや $\mathrm{Ti}$ とも相関をも

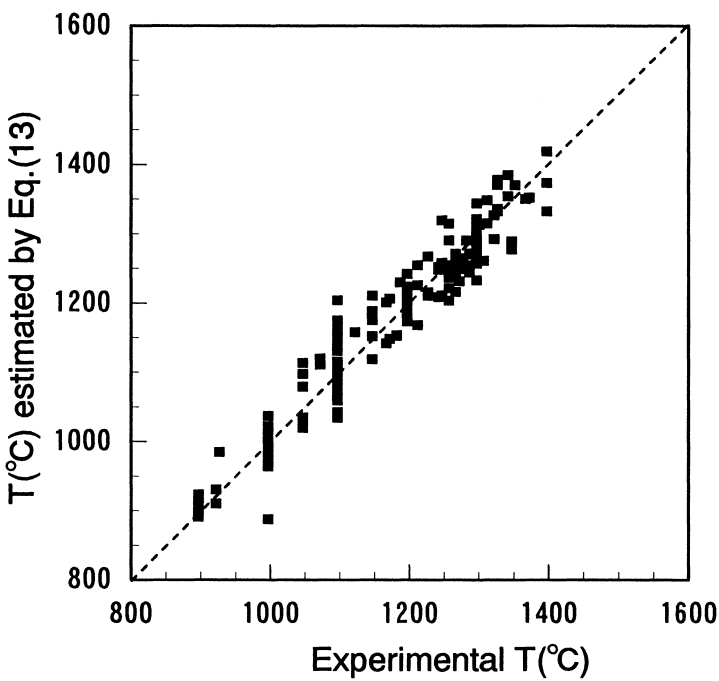

Fig. 8. Correlation between multicomponent experimental temperatures and temperatures estimated by Eq. (13). Data sources are listed in Table 1. Eq. (13) yields temperatures $\pm 35^{\circ} \mathrm{C}(1 \sigma)$ in the multicomponent system.

たない。つまり，Wells (1977) の補正項で他の成分の付加 による平衡定数への影響を説明していることになる。こ のモデルは CMS 系 , 多成分系のいずれでも系統誤差を示 さない(Fig. 8)。(13) 式は多成分系のデータの実験温度を $\Delta T_{\mathrm{M}}=-5^{\circ} \mathrm{C}, \sigma=35^{\circ} \mathrm{C}$ で再現でき (Table 2), 他のモデル より高精度で昷度を見積もることができる。

\section{V. 結論}

公表されている多成分系での単斜輝石一斜方輝石平衡 実験データを用いて既存の輝石温度計を評価した。关の 結果 ,Taylor (1998)のモデルがもつともよく実験条件を再 現できることがわかった。もつとも頻繁に使われる Wells (1977) のモデルは温度 ,圧力に対して系統誤差がみられた ので , この問題点を改良した Wells (1977) の改良モデルを 提案した。このモデルは CMS 系と多成分系のいずれでも 系統誤差がなく，多成分系の実験温度を $\sigma=35^{\circ} \mathrm{C}$ で再現 できた。

謝 辞 本研究をすすめるにあたり柳 哮九州大学名 誉教授には多くの二指導 , ご助言をいただきました。九州 大学の槇山麗子氏には議論していただきました。京都大 学の小畑正明教授には査読して有益なコメントをいただ きました。金沢大学の荒井章司教授には小論を発表する 機会をあたえていただき，有益なコメントをいただきまし た。以上の方々に感謝いたします。

引用文献

Akella, J. (1976): Garnet-pyroxene equilibria in the system $\mathrm{CaSiO}_{3}-\mathrm{MgSiO}_{3}-\mathrm{Al}_{2} \mathrm{O}_{3}$ and in a natural mineral mixture. Amer. Mineral., 61, 589-598. 
Baker, M.B. and Stolper, E.M. (1994): Determining the composition of high-pressure mantle melts using diamond aggregates. Geochem. Cosmochim. Acta, 41, 369-377.

Bertrand, P.B. and Mercier, J.C.C. (1986): The mutual solubility of coexisting ortho- and clinopyroxene: toward an absolute geothermometer for the natural system? Earth Planet. Sci. Lett., 76, 109-122.

Boyd, F.R. (1969): Electron-probe study of diopside inclusions from kimberlites. Amer. J. Sci., 267A, 50-69.

Brey, G.P. and Huth, J. (1984): The enstatite - diopside solvus to 60kbar. Proc. Third Int. Komb. Conf., 2, 257-264.

Brey, G.P. and Kohler, T. (1990): Geothermobarometry in Fourphase Lherzolites II. New Thermobarometers, and Practical Assessment of Existing Thermobarometers. J. Petrol., 31, $1353-1378$.

Brey, G.P., Kohler, T., and Nickel, K.G. (1990): Geothermometry in Four-phase Lherzolites I. Experimental Results from 10 to 60 kb. J. Petrol., 31, 1313-1352.

Carlson, W.D. and Lindsley, D.H. (1988): Thermochemistry of pyroxenes on the join $\mathrm{Mg}_{2} \mathrm{Si}_{2} \mathrm{O}_{6}-\mathrm{CaMgSi}_{2} \mathrm{O}_{6}$. Amer. Mineral., 73, 242-252.

Davis, B.T.C. and Boyd, F.R. (1966): The join $\mathrm{Mg}_{2} \mathrm{Si}_{2} \mathrm{O}_{6}$ $\mathrm{CaMgSi}_{2} \mathrm{O}_{6}$ at 30 kilobars pressure and its application to pyroxenes from kimberlites. J. Geophys. Res., 71, 3567 3576.

Falloon, T.J. and Green, D.H. (1987): Anhydrous Partial Melting of MORB Pyrolite and Other Peridotite Compositions at 10kbar: Implications for the Origin of Primitive MORB Glasses. Mineral. Petrol., 37, 181-219.

Gaetani, G.A. and Grove, T.L. (1998): The influence of water on melting of mantle peridotite. Contrib. Mineral. Petrol., 131, 323-346.

Lindsley, D.H. and Dixon, J.L. (1976): Diopside-enstatite equilibria at 850 to $1400^{\circ} \mathrm{C}, 5$ to $35 \mathrm{kbars}$. Amer. J. Sci., 276, $1285-1301$.

Lindsley, D.H. and Munoz, J.L. (1969): Subsolidus relations along the join hedenbergite-ferrosilite. Amer. J. Sci., 267, 295-324.

Lindsley, D.H., Grover,J.E., and Davidson, P.M. (1981): The Thermodynamics of the $\mathrm{Mg}_{2} \mathrm{Si}_{2} \mathrm{O}_{6}-\mathrm{CaMgSi}_{2} \mathrm{O}_{6}$ Join: A Review and an Improved Model. In Thermodynamics of minerals and melts (Newton, R.C., Navrotsky, A. and Wood, B.J. Eds.). Springer-Verlag, New York, 149-175.

Mori, T. and Green, D.H. (1975): Pyroxenes in the system $\mathrm{Mg}_{2} \mathrm{Si}_{2} \mathrm{O}_{6}-\mathrm{CaMgSi}_{2} \mathrm{O}_{6}$ at high pressure. Earth Planet. Sci. Lett., 26, 277-286.

Mori, T. and Green, D.H. (1976): Subsolidus equilibria between pyroxenes in the $\mathrm{CaO}-\mathrm{MgO}-\mathrm{SiO}_{2}$ system at high pressures and temperatures. Amer. Mineral., 61, 616-625.

Nehru, C.E. and Wyllie, P.J. (1974): Electron microprobe measurements of pyroxenes coexisting with $\mathrm{H}_{2} \mathrm{O}$-undersaturated liquid in the join $\mathrm{CaMgSi}_{2} \mathrm{O}_{6}-\mathrm{Mg}_{2} \mathrm{Si}_{2} \mathrm{O}_{6}-\mathrm{H}_{2} \mathrm{O}$ at 30 kilobars, with applications to geothermometry. Contrib. Mineral. Petrol., 48, 221-228.

Nickel, K.G. and Brey, G.P. (1984): Subsolidus orthopyroxeneclonopyroxene systematics in the system $\mathrm{CaO}-\mathrm{MgO}-\mathrm{SiO}_{2}$ to $60 \mathrm{~kb}$ : a re-evaluation of the regular solution model. Contrib. Mineral. Petrol., 87, 35-42.

Perkins, D., III and Newton, R.C. (1980): The composition of coexisting pyroxenes and garnet in the system $\mathrm{CaO}-\mathrm{MgO}$ $\mathrm{Al}_{2} \mathrm{O}_{3}-\mathrm{SiO}_{2}$ at $900-1000^{\circ} \mathrm{C}$ and high pressures. Contrib. Mineral. Petrol., 75, 291-300.

Pichering-Witter, J. and Johnston, A.D. (2000): The effects of variable bulk composition on the melting systematics of firtile peridotitic assemblages. Contrib. Mineral. Petrol., 140, 190-211.

Schewab, B.E. and Johnston, A.D. (2001): Melting Systematics of Modally Variable Compositionally Intermediate Peridotites and the Effects of Mineral Fertility. J. Petrol., 42, 1789- 1811.

Sen, G. and Jones, R. (1989): Experimental Equilibration of Multicomponent Pyroxenes in the Spinel Peridotite Field: Implications for Practical Thermometers and a Possible Barometer. J. Geophys. Res., 94, 17871-17880.

Smith, D. (1972): Stability of iron-rich pyroxene in the system $\mathrm{CaSiO}_{3}-\mathrm{FeSiO}_{3}-\mathrm{MgSiO}_{3}$. Amer. Mineral., 57, 1413-1428.

Taylor W.R. (1998): An experimental test of some geothermometer and geobarometer formulations for upper mantle peridotites with application to the thermobarometry of firtile lherzolith and garnet websterite. N. Jahrb. Mineral. Abhand., 172, 381-408.

Warner, R.D. and Luth, W.C. (1974): The siopside-orthoenstatite two-phase region in the system $\mathrm{CaMgSi}_{2} \mathrm{O}_{6}-\mathrm{Mg}_{2} \mathrm{Si}_{2} \mathrm{O}_{6}$. Amer. Mineral., 59, 98-109.

Wasylenki, L.E., Baker, M.B., Kent, A.J.R., and Stolper, E.M. (2003): Near-solidus Melting of the Shallow Upper Mantle: Partial Melting Experiments on Depleted Peridotite. J. Petrol., 44, 1163-1191.

Wells, P.R.A. (1977): Pyroxene Thermometry in Simple and Complex Systems. Contrib. Mineral. Petrol., 62, 129-139.

Wood, B.J., and Banno, S. (1973): Garnet-Orthopyroxene and Orthopyroxene-Clinopyroxene Relationships in Simple and Complex Systems. Contrib. Mineral. Petrol., 42, 109-124. 